\title{
The Roles of Lecturers in Education Service: in between Perception and Behaviors
}

\author{
Meta Arief, Umar Faruk, Leny Yulianti \\ Fakultas Pendidikan Ekonomi dan Bisnis \\ Universitas Pendidikan Indonesia \\ metaarief@upi.edu
}

\begin{abstract}
The research will simultaneously obtain a description of the quality of the teaching and learning in terms of affective development in Accounting Education Study Program in institutions of teacher training (LPTK) that were formerly institutes of teacher training and education (IKIP). Through a descriptive survey method and Liker-scaled questionnaire distributed to lecturers. The research found that the lecturers have significantly high perceptions of the philosophical values of accounting in cultivating the habit of discipline, orderliness, and honesty. However, their implementation of the values in real life is only categorized as fairly good, while the implementation in teaching and learning process is categorized as good.
\end{abstract}

Keywords - Perception, Behavior, Lectures, Values, Accounting, , Teaching and Learning.

\section{INTRODUCTION}

Lecturers, as significant human resources, play strategic roles in a higher education institution. As human capital, with the competencies, commitment, and experiences, lecturers are required to be able to create quality teaching and learning process in helping students gain added values under the framework of education goals. According to article 1 of Law Number 20 of 2003 regarding National Education System, education is a conscious and deliberate effort of realizing a learning atmosphere and teaching learning process that allows students to actively develop themselves in order to acquire religious and spiritual power, self-control, personality, intelligence, noble moral, and skills needed by themselves, the society, state, and nation. It is subsequently mentioned in article 3 that the goal of national education is "to develop students' potentials to create faithful and pious human beings, who are simultaneously healthy, knowledgeable, capable, creative, independent, and democratic as well as responsible citizens."

Referencing the Law, it is clear that lecturers' strategic roles are multidimensional and gradual in nature, where in addition to teaching, they serve as parents, educators, managers, servants, producers, supervisors, facilitators, motivators, and resources (1)(2)(3). With this multidimensional role, lecturers will be looked-up to by their students, and their positive behaviors will be imitated by and transferred to the students, either deliberately or not. Therefore, the goals of education will be thoroughly met if lecturers are able to behave positively and apply their knowledge in their daily lives, including in the teaching and learning process.
Educating is a process of developing and actualizing the best potentials through learning, which is a process carried out by an individual in order to realize transformations of positive behaviors, as a result of his or her own experience and interaction with the environment. Lecturers' understanding and skills in teaching their field of knowledge should not be questioned; however, the undeniable understanding and skills in teaching are not necessarily parallel to the ability in applying the values of their field of study in their daily lives. One of the functions of a lecturer in educating is to transfer and develop life values (4) (5).

In the context of educators in the field of accounting, the values of accounting are found in the activity related to financial transactions, starting from identifying, recording, classifying, and summarizing the transactions in order to make a report. The activities of recording and classifying are routinely and repeatedly undertaken every time a financial transaction takes place, while reporting is only done at certain times (6). Based on the activities, it is clear that accounting entails the values of orderliness, honesty, and discipline. It is orderly because in accounting, the job is done procedurally, where the first things to do are to identify and record all documents of financial transactions in chronological order. It requires honesty, as whatever is recorded as a financial transaction should be based on adequate and valid proof. Finally, it requires discipline, for all accounting activities should be done on time, without any delay. Based on the activity flow, it is obvious that when applied in real life, both for financial and non-financial matters, accounting values will highly encourage the development of positive behaviors.

It is then very strategic if the positive behaviors are not only cultivated among family members or in the immediate environment, including students, but they should be first cultivated in the individuals themselves. Accounting lecturers' understanding and skills in teaching accounting should not be questioned; however, it does not necessarily mean that they will similarly be able to apply the accounting values in their daily lives. Meanwhile, accounting does not solely aim at cognitive and psychomotor development, but also affective development, through the implementation of accounting values.

\section{THEORETICAL FRAMEWORK}

The essence of education is learning, which is "transformation of behavior or appearance, through a series of 
activities, such as reading, observing, listening, mimicking, and the like" (7). In addition, "Nowadays, the new paradigm of education does no longer lie in the significant transfer of cognitive knowledge, but it should be accompanied with practicing the knowledge (doing) and internalizing it (being). Therefore, education should no longer be oriented at academic dimension, in the forms of theory and concept, but also at the pragmatically dimension, through the application of the theory and concept, in order to create a whole and outstanding individual" (8).

Meanwhile, teaching and learning is a set of actions designed to support students' learning process, by considering the external events that have impacts on the series of ongoing internal events within the students (9). Sails adds that assessing the quality of education service is highly different from appraising other goods or services, for education service contains the complexity of learning process accompanied by each individual student's uniqueness. Another opinion put forward by Agus (10) states that character education in school is highly influenced by teachers' behaviors. Teachers' negative behaviors can kill children's positive behaviors; on the other hand, teachers' positive behaviors will be able to develop and strengthen children's positive characters.

Attitude is inner feeling reflecting one's happiness or unhappiness, like or dislike, agreement or disagreement with an object (11). It is an individual's thorough evaluation of a concept, where the evaluation is first made based on one's belief that the object possesses certain attributes, and the second evaluation is concerned with the attributes (Martin Fishbein's model). Positive evaluation will form trust, and attachment is the one that drives certain attitude or behavior (12). There are three important components that form attitude: 1) cognition, 2) affection, and 3) conation. The interaction of the three complex attitudes causes the cognitive component to answer to what is thought or perceived of a certain object. Affection will respond to what is felt (happiness or unhappiness) about the object. Meanwhile, conation is a tendency to act based on the readiness to behave in a certain way with a certain goal (13).

Ideally, one's attitude is consistent with his or her behavior; however in reality, this is not the case. Behavior departs from attitude, but attitude is a result of perception. Perception itself is, as explained by Samsunuwiyati (14), a result of observation of the five senses that takes place every time the senses receive stimuli as perceived by the nervous systems, and the process is adjusted to each individual's needs. Skinner's theory (1938) states that behavior is one's response or reaction to external stimuli and it takes place through a process. Furthermore, the principle of character development in schools asserts that values are not taught, but continuously developed in learning process, through all subjects, starting from the students first get enrolled until they graduate (15).

Value development takes several stages, such as: value internalization, modeling/example, habituation, and creation of an atmosphere characterized with values and ethics in schools. Internalization is an effort of providing understanding of such attitudes as honesty, discipline, and religiosity. Modeling is done by teachers of lecturers giving real examples of good behaviors. Meanwhile, habituation is a process of value cultivation developed and applied in daily life. Finally, value system should be created in order to achieve shared vision and missions (10). Arfan (16) said, "all human beings have a hierarchy of values that form value system, where the system is identified for relative interests, and accounting is concerned with human beings, where it is an action, meaning that no matter how sophisticated it is, the process of accounting is not the end goal, accounting service is not merely a technique, and its effectiveness does not solely rely on the procedures, but on the behaviors of its users and executors. Especially for teaching, a lecturer's job according to Alvin W. Howard as cited in Slameto (17) is to help and supervise a student to acquire, transform, or develop skills, attitude ideals, appreciations, and knowledge.

\section{RESEARCH METHOD}

Based on the stated goals above, namely to obtain a profile of lecturers and quality of teaching and learning in LPTKs that were formerly state IKIPs, the research adopted a descriptive survey method. The objects of this research were 12 LPTKs that used to be State IKIPs. A preliminary survey shows that these LPTKs hold the Study Program of Accounting Education. The population consisted of lecturers of Accounting Education Study Program. Sample for the research objects was taken purposively, while sample for lecturers of Accounting Education Study Program was taken with simple random sampling technique, without taking into account their ranks and positions.

The sample in this research comprised lecturers of the Study Program of Accounting Education from the following universities

- Indonesia University of Education in Bandung, representing West Java,

- State University of Yogyakarta, representing Central Java, and

- State University of Malang, representing East Java.

Data analyzed based on temporal and spatial dimensions are considered as cross-sectional data. The primary data were in the form of ordinal data gathered through indirect communication via questionnaire. Each item in the questionnaire refers to variables measured using Liker scale, where each number has stratified meanings.

The questionnaire was made in a six-scale, with the provides the following formula to determine a range of score for a descriptive survey take from Umar (18) and Simamora (19) :

$$
K S=\frac{n(m-1)}{m}
$$

Notes:

RS : Range of Score

$\mathrm{N}$ : The Number of Sample

M : The Number of Alternative Answers (15)(16) 


\section{FINDINGS AND DISCUSSION}

Considering the faculties of economics in the sample universities are structurally different, it is possible that the lecturers who teach at the Study Program of Accounting Education are those whose home base is in the undergraduate study program of accounting education and those whose home base is pure Accounting Study Program, both for bachelor's and Diploma 3 degrees. Therefore, the questionnaire was distributed only to lecturers of pure Accounting Study Program who were assigned to teach in the Study Program of Accounting Education.

It is found that on average, the perception of Accounting Education lecturers of the philosophical values of accounting is in the category of very good. Of the ten questions posed, nine are categorized as good. Accounting Education lecturers perceive that accounting upholds the values of orderliness, honesty, ad discipline, because in accounting activity, an individual is taught how to record, gather proofs of financial transactions, and followed by making periodical reports.

If the accounting values of honesty, orderliness, and discipline have been developed, one can minimize the risks of problems in his or her life. Fraud and mark-up are practices disadvantageous for many parties, and in this case, lecturers of Accounting Education Study Program are in the perception that the practices should be avoided by one who has acquired accounting knowledge and skills.

Based on the results of questionnaires, it is found that on average the lecturers' behaviors are categorized as "tend to be good" or fairly good. Although their perception is very good, in practice it is not always the case. Attitude is a tendency; therefore, it is not always followed by certain responses in the forms of behaviors. For the item of "As an accounting lecturer I always try to be honest in doing anything," the lecturers' responses are categorized as very good.

In terms of orderliness in financial administration, Accounting Education lecturers are in the category of good, as reflected by their habit of asking for bills or receipts after shopping or receiving from or transferring something to another party. This habit shows that the value of orderliness in accounting has been well-reflected in the lecturers' daily lives.

In terms of honesty in expressing opinion, recording daily personal income and expenses, recapitulating family and personal income and expenses, and analyzing family and personal income and expenses, the lecturers of Accounting Education are categorized as fairly good. Hence, although the values of honesty, orderliness, and discipline are required in accounting activities, the lecturers of Accounting Education Study Program have not been able to practice them in their daily lives, especially in family and personal financial management.

\section{CONCLUSIONS AND SUGGESTIONS}

Descriptively, the lecturers' perception and understanding of accounting philosophical values have been very good. This category means that the lecturers acknowledge that the teaching and learning of accounting entails the values of orderliness, honesty, and discipline. However, their very good perception of accounting philosophical values does not necessarily mean that they are able to apply the values in daily life, for they are still at the stage of having the inclination to try to apply the values. Nevertheless, they have implemented the values in the teaching and learning as an attempt of developing students' affective dimension in order to help them be orderly, honest, and discipline fairly well.

Based on the findings, it is recommended that lecturers create assignments for students that can encourage and habituate the students with the attitudes of orderliness, honesty, and discipline in terms of financial management.

\section{REFERENCES}

[1] Tampubolon, Daulat P., Perguruan Tinggi Bermutu Paradigma Baru Manajemen Pendidikan Tinggi Menghadapi Tantangan Abad ke-21, PT Gramedia Pustaka Utama, Jakarta, 2001: 173

[2] Eko Indrajit, R. \&R. Djokopranoto, Manajemen Perguruan Tinggi Modern, Andi Offset, Yogjakarta, 2006 : 340

[3] Engkoswara, Ilmu dan Teknologi Pendidikan, Yayasan Amal Keluarga Bandung, 2001: 3

[4] Usman, H., Manajemen: Teori, Praktek dan Riset Pendidikan, Bumi Aksara, Jakarta, $2006: 7$

[5] M.N. Nasution, Total Service Management, Manajemen Jasa Terpadu, Ghalia Indonesia, Bogor, 2004 : 103

[6] Haryono Jusup, Al, Dasar-dasar Akuntansi, STIE YKPN, Yogyakarta, 1992 : 11-15

[7] Sardiman, Interaksi \& Motivasi Belajar Mengajar, Grafindo Jakarta, $2007: 20$

[8] Abuddun Nata, Perspektif Islam Tentang Strategi Pembelajaran, Kenca Prenada Media Group, Jakarta, $2011: 19$

[9] Rahman, Muhammad, dan Sofyan Amri, Strategi dan Desain Pengembangan Sistem Pembelajaran, Prestasi Pustakaraya, 2013

[10] Agus Zaenul Fitri, Pendidikan Karakter Berbasis Nilai dan Etika di Sekolah, Ar Ruzz Media, Yogyakarta, 2012

[11] Schiffman Kanuk, G Leon, Leslie Lazar, Consumer Behavior, Prentice Hall, Seventh Edition, New Jersey, 2007 : 15

[12] Peter, J. Paul, Jerry C. Olson, Consumer Behavior, Perilaku Konsumen dan Strategi Pemasaran, Erlangga, Jakarta. , $2000: 6$

[13] Engel, F. James; Roger D Blackwell; Paul W. Miniard, Consumer Behaviour, Dryden Press, Horcout Brace College Publisher, 2001 : 325

[14] Samsunuwiyati Mar'at, Lieke Indieningsih Kartono, Perilaku Manusia Pengantar Singkat Tentang Psikologi, PT. Refika Aditama, Bandung, $2010: 10$

[15] Kemendikbud, Pemerintah Republik Indonesia, 2010, Kebijakan Nasional Pembangunan Karakter Bangsa Tahun 2010-2015

[16] Arfan Ikhsan, Muhammad Ishak, Akuntansi Keperilakuan, Salemba Empat, Jakarta, $2005: 21,63$

[17] Slameto, Belajar dan Faktor-Faktor yang Mempengaruhinya, Rineka Ciptam, Jakarta, $2003: 32$

[18] Husein Umar, Metode penelitian Bisnis, PT Gramedia Pustaka Utama,Jakarta , 2002 : 226-244

[19] Bilson Simamora, Panduan Riset Perilaku Konsumen, PT Gramedia Pustaka Umum, Jakarta. , 2004 : 202 